Original Article

Received/Accepted Dates

28.04.2021/20.06.2021

DOI:

10.52096/usbd.5.23.5.5

\section{Uluslararası Sosyal Bilimler Dergisi}

International Journal of Social Sciences

www.sobider.net

ISSN: 2548-0685

Cultural Diversity in Igbo Life: A Postcolonial Response to Chinua Achebe's Arrow of God

Assistant Professor Md. Sazzad Hossain Zahid

Department of English

Islamic University, Kushtia, Bangladesh

sazahid1400@gmail.com

\title{
Cultural Diversity in Igbo Life: A Postcolonial Response to Chinua Achebe's Arrow of God
}

\begin{abstract}
In his book Chinua Achebe, David Caroll (1980) describes the novel Arrow of God as a fight for dominance both on the theological and political level, as well as in the framework of Igbo philosophy. In Critical Perspectives on Chinua Achebe (1990), famous Achebe critics C. L. Innes and Berth Lindforts consider Arrow of God as a novel with conflicting ideas and voices inside each community with the tensions and rivalries that make it alive and vital. Another profound scholar on Achebe Chinwe Christiana Okechukwu (2001) in Achebe the Orator: The Art of Persuasion in Chinua Achebe's Novels assesses Arrow of God, which depicts a community under imminent danger of cultural genocide unleashed by agents of Western imperialism who have recently arrived in the indigenous society. However, the author in this study attempts to see Arrow of God as a postcolonial response to cultural diversity that upholds its uniting and cohesive force in Nigerian Igbo life. The goal is to look at how Achebe, in response to misleading western discourses, develops a simplistic image and appreciation that persists in Igbo life and culture even as colonization takes hold. This paper also exhibits how the Igbo people share their hardships, uphold their age-old ideals, celebrate festivals, and even battle on disagreements. This study employs postcolonial theory to reconsider aspects of cultural diversity among the African Igbo people, which are threatened by the intervention of European colonialism in the name of religion, progress, and civilization.
\end{abstract}

Key Words: Diversity, Cultural Diversity, Igbo people, postcolonial, Western discourse, colonialism 


\section{Introduction}

Diversity is a fundamental term in this study, as it allows us to approach African cultural variety as a uniting and cohesive force. In western discourses, the beauty of this ethnicity and diversity in African culture is not frequently appreciated; rather it is undervalued or ridiculed. Arrow of God by Chinua Achebe (1964), is a remarkable account of the culture, cultural diversity and way of life of the people of a region in Africa, written over the Igbo community in colonial Nigeria. Chinua Achebe (1930-2013) performs a major role in the body of postcolonial literature, both as a writer and as a critic, as an author whose works are widely read and studied academically around the world. As a leading character in African postcolonial literature, as well as African intellectuals, writers, critics, and poets, he criticized the colonial literature's propaganda that portrays precolonial Africa as barbarous and chaotic. In his work, Achebe (1930-2013) addresses the ideology that underpins Africans' "inferiority complex," particularly among Igbo people, and builds an alternate history in which he leverages the Igbo community's functioning structures and customs to demolish Europe's long hegemonic narrative. This has given him international exposure as well as the capacity to reach out to other English-speaking African countries, where he has provoked comparable responses. His works highlight the determination of all Africans and oppressed people to combat challenges in order to maintain their identity. He advocated for the eradication of colonialist-created prejudices. The Arrow of God is an example of iconography that is essentially a postcolonial response of the Igbo society and their cultural diversity.

The story depicts the unity and diversity of the Nigerian Igbo community, with Achebe (1964) deftly describing the cultural variation, agreement, and dispute among them. Achebe (1964) shows that the Igbo people have their own vision of the world, one that includes close connection with supernatural beings. Superstition and supernatural forces have an impact on their daily lives. They are extremely religious people that believe in ancestral gods and ancestor spirits. In addition, the village is seen as a totemic, ideological, and religious institution. Their lives are undeniably influenced by economic activities. Meanwhile, the British colonial powers wreaked havoc on Igbo society with their military, religious, and other machineries, but Achebe (1964) did not shy away from showcasing the richness of the Igbo society's own culture. There are, however, moments of ambiguity between the Igbo community's traditional beliefs and the ideals taught by the colonizer's 
new religion. This ambivalence drives Ezeulu, the top priest in the novel, to send his son to learn the white man's ways and beliefs. This ambiguity was born out of the confusion created among the people of the Igbo community as a result of the growing control of the colonial power. As a result, the normal beliefs of Igbo society, religion, festivals and coexistence led to general quarrels, terrible mistrust and conflict. This conflict took the form of a new kind of pros and cons. This novel, which is almost a century old, has been analyzed and assessed by critics and scholars from all over the world in the past. While it is impossible to address all of them in this article, the author will attempt to summarize some of the significant issues. However, the main focus of the author's discussion is to unveil the beauty of cultural unity and diversity among the people within the Igbo community. The author also aims to demonstrate how, as a postcolonial response, the strong heritage and dynamism of this cultural diversity deconstructs the false narrative of European superiority.

Many have referred to this dynamism in society as a cultural transformation. In Arrow of God, the Chief Priest Ezeulu's experience, knowledge, pragmatism, intelligence, full understanding of all people in the society is the reflection of a wise leader, a continuation of the many old traditions of the Igbo society. However, the position of the Chief Priest is almost shaky as a result of the Evil invasion of the European colonizer. Many of those who in the past have obeyed his orders, advice or general words without uttering a word are daring to argue with him unnecessarily. The most daring are some young people, many of whom are being brainwashed by the European colonizers. It is very difficult to keep his head cool in this new situation. As a result, intolerance is growing between the words and deeds of the Chief Priest. Many times he cannot maintain his normal temper.

\section{Literature Review}

Many scholars demonstrate how Achebe's writings reflect the innovative mark of African culture through their distinct portrayals of the Igbo people, making him one of the pioneering examples of African writing. This story depicts Africa's revolutionary response to colonial Europe's portrayal of Africa as a barren wasteland devoid of human significance. Things Fall Apart, No Longer at Ease and Arrow of God are considered to be the most significant milestones of Achebe's (1958, 1960, 1964) work on the background of pre-European colonies, European colonies and their rule 
and exploitation in Africa. On the one hand, each of the three novels shows the agony of losing Africa's own culture, as well as demonstrating the Igbo people's natural culture and cultural diversity as a tactic of anti-colonial struggle, which is one of Achebe's trademarks. In this context, The Arrow of God has become a major breakthrough in the socio-economic and cultural milieu of Africa as a vivid illustration of the voice and awareness created by the recovery of subconscious and troubled Africans in times of historical crisis. The critics' debates reveal the novel's many facets, as well as its essential characters and themes. Abba A. Abba (2019) regards Ezeulu, the chief priest's stance as "heroic madness." Nirupa Saikia blames "the individual and socio-political factors leading to the fall of Ulu. ( "From Heroism to Madness", p. 1057)" Meanwhile, Ikechukwu Sunday Onyibor (2016) focuses on "traditional Igbo religion, politics, philosophy, and art," all of which have "meaning to Igbo traditional" life and culture ("Igbo Cosmology", p. 113). Chijindu Daniel Mgbemere (2013) thinks that Arrow of God (1964) is an example of "profound capturing of the dominant life style of the colonial and pre-colonial Igbo nation" that "duo brings one to the appreciation of the Igbo world before the erosion of colonialism ("Cues in Igbo Cultural Matrix", p.19)" while Amechi Nicholas Akwanya (2013) looks at the power of the chief priest, Ezelulu in the novel ("The Power of the Unknown", p. 38). In tune with Chijindu Daniel Mgbemere (2013), Zéphirin BOKOTIABATO MOKOGNA (2019) states that "each village had its socio-traditional way of living before they came into contact with the Western culture. ("Insight into the Ibo SocioTraditional Organization", p. 139) A profound critic and scholar, F. Abiola Irele (2009) regards Achebe as a postcolonial novelist whose "choice of this form has deep historical roots. For the novel form is both the product and medium of the historical process." (African Novels, p.33) He further states that “Achebe's tragic fiction can be explained by his interpretation of Igbo cultural history, the dignity and validity of Igbo culture." (African Novels, p. 34) For him, Achebe gives "its subjects the right to tell their own stories." (African Novels, p. 34) David Caroll (1978) places the novel Arrow of God as "a struggle for power both on the religious and the political level, and in the structure of Igbo thought." (Chinua Achebe: Novelist, Poet, Critic, p. 91)" Famous critics of Achebe, C. L. Innes and Bernth Lindfors (1990) observes Arrow of God as a novel with "contrasting views and voices within each community" with "the tensions and rivalries which make it active and vital. (Chinua Achebe, p. 71)" In his book, Achebe the Orator: The Art of Persuasion in Chinua Achebe's Novels, Chinwe Christiana Okechukwu (2001) observers the 
absence of leadership during the time of political need. (p. 46) He further regards Western aggression as a cultural genocide on the indigenous people and their culture. He states:

Chinua Achebe has demonstrated, through Arrow of God, the power of rhetoric in forging and influencing a society's choices. He has demonstrated the calamity that could overtake a society that does not have a rhetorician to guide it in its time of political need. Such a time is exemplified in the novel as the time that society is in imminent danger of cultural genocide unleashed by the agents of Western imperialism who have just settled in the indigenous society. (Achebe the Orator, p.46)

However, all the Achebe scholars and critics of his works mentioned above somehow miss the question that this author tries to focus; the cultural diversity of Igbo life and promotion of culture as the response to colonial enterprise. In response to all of the excessive conventional clichés of European intellectuals, Chinua Achebe (1930-2013) depicted the simple lifestyles of African people in his novels. He did so without resorting to vanity or hyperbole in the process. There is no critique of European civilization in any of his texts. There is no attempt to demonstrate that African civilization is superior to that of Europe. The novel in this study is no difference. By depicting the actual African character as his nature, Achebe (1964) has depicted the life and cultural diversity of the African people in a disinterested manner in this novel.

\section{Arrow of God: A Postcolonial Response}

John C. Hawly's (2001) understanding of culture is been "always a specific form of sense making, through neither uniform nor monolithic (Encyclopedia of Postcolonial Studies, p. 123)" agrees with Homi K. Bhaba's (1994) concept of “culture as an object of empirical knowledge." (The Location of Culture, p. 34) This sense-making occurs as a result of the people's lives and practices that Hawly (2001) interprets "as being always the lived traditions, practices, and material conditions of life and meanings and values connected with them." (Encyclopedia, p. 123) All of these conditions and practices are not static, and they always raise concerns about the forcible imposition of a foreign culture or the rapid disappearance of a previously practiced one. Even a 
seemingly modest exercise can be extremely valuable to those who engage in it. Thus, "culture is ordinary and voiced his concern about the exclusions practiced by selective traditions of culture. (Hawly, 2001, p. 123) A culture in this sense is a creative network of power relations, the embodiment and site of antagonistic relations of domination and subordination, as a result of such dynamic and absorbing engagement between culture and the practicing people. (Hawly, 2001, p. 123) In cultural studies, culture is "a contested and conflictual set of practices of representation bound up with the processes of formation and re-formation of social groups. A culture in this sense is a productive network of power relations, the embodiment and site of antagonistic relations of domination and subordination." (Hawly, 2001, p. 123) A dynamic society is characterized by competition, conflicts, and "disagreement" between two or more groups of people. Homi K. Bhabha (1994) states:

Cultural diversity is the recognition of pre-given cultural 'contents' and customs, held in a time frame of relativism; it gives rise to anodyne liberal notions of multiculturalism, cultural exchange, or the culture of humanity. Cultural diversity is also the representation of a radical intertextuality or their historical locations, safe in the Utopianism of a mythic memory of a unique collective identity. (The Location of Culture, p. 34)

The beauty of Achebe's (1964) Arrow of God is that it depicts the cultural diversity of the Igbo community, where "mythic memory" (Bhabha, 1994) is interwoven in every aspect of their lives. Despite their cultural differences, Igbo clans share a "unique collective identity" (Bhabha, 1994) based on a shared "mythic memory." Homi K. Bhabha's (1994) statement about culture "as an object of empirical knowledge (34)" prompts us to look into Hawly's (2001) statement that "cultural studies is always a dynamic, multifaceted enterprise." (124) In this context, Chinua Achebe's (1964) Arrow of God delves into the topic of cultural diversity with a particular focus as "[the] investigation of everyday life is connected with the new awareness that when people are at their most natural, their most everyday, they are also at their most cultural.” (Hawly, 2001, p. 124) This investigation looks into how people interact with religion, customs, the economy, and numerous individual and societal contacts. "In this way, cultural studies is always connected with the narratives and with human activities. Narration, in particular, is regarded as a basic activity giving meaning to human life." (Hawly, 2001, p. 128) Despite living in the same society due to the innate diversity of people, there are differences. This distinction might be seen in how people 
show themselves, how they use language, how they communicate their interests, or how they live a cultural life. Tanure Ojaide (2018) states, "Even within an ethnic group, despite the common language spoken, there is still diversity in different clans and the subgroups. The diversity within one group could be in the form of dialects of the language and variations in the cultural practices." (Global Africa, p. 2)

However, the development of cultural studies has coincided with postcolonialism and so shares with it many interests and perspectives, such as the concern with everyday life and the power structures that influence human activities." (Hawly, 2001, p. 130) Bloody conflicts, the result of confrontations between different levels of authority in society, often take the shape of multidimensional unity and division amongst different clans and groupings. The colonial rulers' presence, their display of authority, and the rise of mistrust in the local people's relationships made the regular feuds between themselves and the outside clan unique. Nevertheless, acknowledging various aspects of cultural diversity in Igbo society with the lens of cultural studies, it can be said that "the development of cultural studies has coincided with postcolonialism and so shares with it many interests and perspectives, such as the concern with everyday life and the power structures that influence human activities." (Hawly, 2001, p. 130) In this context of postcoloniality, Robert J. Young (2001) states, "Postcolonial theory formulates its critique around the social histories, cultural differences and political discrimination that are practised and normalised by colonial and imperial machineries." ( Postcolonialism, p. 57) Achebe's (1964) Arrow of God is a postcolonial novel, which deals with society, history, cultural diversity, colonial hegemony, and a counter discourse to the European narrative.

A counter discourse against the European narrative is so significant for Nigeria and Africa as a whole because "European colonial rule in Africa was more effective in destroying indigenous African structures than in destroying African culture ( Mazuri, 1986, p. 20)" since “...culture is what determines people's real lives, their identities, their values" (Hawly, 2001, p. 126). Thus, John C. Hawly's (2001) "culture" as the determiner of "people's real lives" (p. 126) that identifies "their identities, their values" (p. 126) is uphold by Chinua Achebe (1964) in the novel Arrow of God. The colorful and diverse culture of Igbo society, cultural diversity, personal and social life, hospitality, friendships, the interrelationships of each family member, the interrelationships of each person in society, and the overall life as a panoramic scene are depicted throughout the novel Arrow of God. Igbo people's lives are heavily influenced by their traditional religion and rituals. 
Its foundation is based on the inherent energy of human life and the intimate connection between each member in the society. However, the most important consideration in the complete understanding and involvement in the actions of each individual, which is usually conducted through rituals, is the real celebration of life. The presence of diversity and conflict is obvious in every sector of the Igbo people's lives because their lives are intertwined with ritual-based religious activities and a succession of cultural activities. Meanwhile, the society's beauty is the balance between dispute and resolution, which is governed by the Chief Priest and invisible deities, as well as the elders' assistance. Using fiction in Arrow of God, Achebe (1964) depicts a vivid image of an Igbo community that is strongly reliant on their own perspective of existence with traditional, spiritual entities.

The triumph of British colonial power over the Igbo population and the supremacy of Christianity are shown as highly inevitable at the novel's conclusion. Chief Priest Ezeulu's strong effects have also been highlighted. Without a doubt, the novel's central character, Chief Priest Ezeulu, and the other characters around him have revealed their significance; and, depending on these characters, the main focus is, of course, the extraordinary description of each event, ranging from the smallest to the biggest in Igbo society. In this novel, Achebe (1964) weaves together multiple narratives and a large cast of characters to provide a straightforward, realistic depiction of the family, its members' interrelationships, and their ties with their neighbors, and their roles in society. There are periodic quarrels amongst family members, just as there are love connections. People with various beliefs, vocations, and identities coexist in a society. Even living next door to each other can result in cultural disparities within the same community. Similarly, cultural differences between societies grow through time until they reach a point where they become a major source of contention. As a result, Achebe's (1964) novel is a memorable account of the whole life of Igbo society, in which each of the aforementioned issues has a realistic presence.

Although this novel can be studied in a variety of ways, the author has split it into three parts based on the Igbo people's way of life, cultural unity, and differences. The first is the picture of family life in Igbo social life, as well as the relationship and value amongst family members. The second is the Igbo community's cultural unity, the beauty of the various religious and social rituals. Third is the diversity and variances in beliefs and customs based on the Igbo people's social, cultural, and religious lives. However, the name Ezeulu is directly and indirectly involved in each of the subjects mentioned in Achebe's (1964) Arrow of God; that is to say, the Chief Priest, Ezeulu has 
the outstanding influence and control over every small event in Igbo life from birth to death. Last but not the least, the novel is set in colonial Nigeria, with the British colonial authority intervening at various occasions, but this has minimal bearing on the story's core theme, the culture of Igbo society, and the celebration of cultural diversity.

\section{Cultural Diversity of Igbo Life in Arrow of God}

Arrow of God is a novel about a Chief Priest named Ezeulu of Umuachala in Igboland. Ezeulu is the Chief Priest of Umuaro's entire territory. Because of his heavenly powers, he has jurisdiction over the six villages of Umuaro. He is a man of great respect throughout the region, and he is in charge of religious ceremonies and rituals. With three wives and eight children, Ezeulu enjoys an affluent and wealthy household. As a religious leader, he assumes a variety of tasks for his villagers. One of his primary jobs is to count the New Moons and declare the day of the New Yam Feast. Achebe, through the family of Ezeulu portrays the values and relationship of the family members prevailing in Igbo society. A family in Igbo community bears strong comradeship and respect to each other. Respecting elders and helping in family activities are quite common in each family. On one occasion, Edogo, the son of Ezeulu proposes his father:

"Tomorrow is Afo," said Edogo, "and we have come to find out what work you have for us."

Ezeulu thought for a while as though he was unprepared for the proposal. Then

he asked Obika how much of the work on his new homestead was still undone.

(Achebe, 1964, p. 12)

At the time when Ezeulu's dearest son Obika prepares for marriage, Ezeulu decides to set a new house for him and orders other members to help him.

Of late another small compound had been built on the other side of Ezeulu's for his second son, Obika. But it was not quite as small as Edogo's. It also had two huts, one for Obika and the other for the bride who was soon to come. (Achebe, 1964, p. 90)

On many occasions in the novel, Achebe (1964) highlights the values and comradeship that prevails in Igbo families, as we see Ezeulu instructs everyone in the family to work collectively. He says: 
"Tell them that tomorrow is the day on which my sons and my wives and my son's wife work for me. Your people should know the custom of this land; if they don't you must tell them. Do you hear me?"

(Achebe, 1964, p. 13)

Aside from load sharing, there are times when we see family members, particularly women and children, playing together or listening to elders' stories, demonstrating strong family ties. There is also hint of taking food with great celebrating manner:

Her daughter, Obiageli, and Akueke's daughter, Nkechi, were telling each other stories. Nwafo sat on the small mud-seat at the foot of the hut's central pillar watching them with a superior air and pointing out now and again their mistakes.

Ugoye stirred the soup on the fire and tasted it by running her tongue on the back of the ladle. (Achebe, 1964, p. 65)

When Ezeulu was staying under the informal custody of the British colonial authority, his family members visited him with great emotion and anxiety. Even then, Ezeulu was asking situation of his house and taking details of every family members. This shows affection of a father towards his family:

"How are the people at home, Ugoye?"

"They were well when we left them." Her neck looked shorter from carrying the load.

"The children, Obika's wife and all the others?"

"Everybody was well."

" And what about the people of your household?" he asked

Akuebue.

"They were quiet when I left them. There was no sickness only hunger." (Achebe, 1964, p.p. 167-168)

Besides values and culture of the family life, there are various episodes in Arrow of God that tell us about the Igbo people's culture, society and diversity. Most part of this novel exhibits several Igbo customs, traditions, rituals, superstitious beliefs, religious activities, celebrations, and art. Daily rituals, rituals for sick people, the role of the medicine man, marriage, friendship, funerals, sacrifice, hospitality, communal comradeship, festival celebrations, and so on are all depicted masterfully by Achebe. 
The concept of God, deities, and the Chief Priest are all well-explained in the story. The people require an authoritative figure to inform them about the rites and traditional ceremonies, as they are closely linked to their crops and livelihood. There is a mention in the novel's tale to how the six communities of Umuaro chose their common deity and named it Ulu, as well as appointing a chief priest named Ezeulu. When the villagers of Umuaro create a deity for themselves, they feel quite secure and safe. They think that their common deity guards them against all threats. Many superstitions and religious beliefs are practiced by the Igbo people. They believe in ghosts, good and evil spirits, as well as their deities. They also identify these spirits and deities with a variety of things. These associations appear to originate from fear as well as a rule or system for a society's regulated life. Obika, Ezeulu's dearest son, was a tiny boy when he encountered a ghost spirit and became terrified. Ezeulu enquired about the spirit he had seen and we knew Eru, Idemili, and Ogwugwu were the spirits he encountered from the conversation between the two:

...was dressed like a wealthy man... had an eagle's feather in red cap... carried a big tusk across his shoulder... Then it is Eru, the Magnificent... When he likes a man, wealth flows like a river into his house; his yams grow as big as human beings, his goats produce threes and his hens hatch nines... (Achebe, 1964, p.p. 8-9)

The people of Umuaro also believe that even their market place is governed by some deity. It shows their passionate engagement with their beliefs. They believe that there is a powerful deity made by the people of Okperi to control the market place. “... This deity called Nwanyieke is an old woman... beckoning with her broom in all directions of the earth and drawing folk from every land..." (Achebe, 1964, p. 20). There is another deity, Idemili, who is regarded as one of Umuaro's deities. The priest Ezidemili describes: "Idemili means Pillar of Water. As the pillar of this households roof so does Idemili hold up the Raincloud in the sky so that it does not fall down. Idemili belongs to the sky..." (Achebe, 1964, p. 43).

In the religion of the Igbo people, prayer, like every other religion, has its own special importance. They pray to their gods on a regular basis. The Chief Priest and the elders pray for the clan's wellbeing. They pray for good health, prosperity, and fortune. When Ezeulu views a new moon at the start of the story, he prays for the well-being of the entire Umuaro people:

"Ulu, I thank you for making me see another new moon... This household, may it be healthy and prosperous...We may increase in numbers at the next 
counting ... May children put their fathers into the earth and not fathers their children..." (Achebe, 1964, p. 6)

Aside from their belief in deities, Igbo people rely on a variety of people to carry out their various roles and responsibilities; one of them is the medicine man who is important on the occasion of marriage and funeral as well. He makes the sacrifice of a cock, goat, or bull as part of the marriage ritual, depending on the ability of the families. On the occasion of Obika's marriage, the medicine man performs the sacrifice ritual. Achebe narrates:

... medicine-man chose a spot in the middle of the way and asked Obika to dig a hole there and make it wider... then a bunch of cowries was given to the medicineman. The medicine-man then asked Okuata, the new bride to put the cowries, the palm leaves, and the hen into the hole and cover it with the fired clay. This sacrifice is performed in order to bring security and prosperity in the life of the newlywed couple. (Achebe, 1964, p. 121)

During the funeral of an elderly man named Amalu in the village, the body of the deceased individual is buried, and offerings are made. Before he dies, Amalu tells his son a few things. He informs him that his burial must not be postponed for more than four moons after his death. During the burial, he also orders his son to slay a bull as a sacrifice. Amalu says:

"I would have said: Do it a day or two after I have been put into the earth. But this is ugani; I cannot ask you to arrange my burial feast with your saliva. I must wait until there are yams again... But you must not delay it beyond four moons from my death. And do not forget, I want you to slaughter a bull.” (Achebe, 1964, p. 217)

The Igbo people's natural belief system includes the existence of various gods and goddesses, as well as reliance on priests and medicine men. Apart from this, hospitality is a distinguishing aspect of Igbo culture. Hospitality is no exception, since spirituality, religion, beliefs, and rituals are intricately intertwined with practically every single event and culture in the Igbo community. Achebe makes frequent references to the custom of cracking the Kolanut when welcome visitors into the home in his novel Arrow of God (1964). The chat between Ezeulu and his friend Akuebue that follows will explain the Kolanut cracking custom.

“... 'Then break it.'

'No. The king's Kolanut returns to his hand.' 
Ezeulu picked up the kolanut in his right hand and offered a prayer. He jerked the hand forward as he said each sentence, his palm open upwards andthe thumb holding down the kolanut on the four fingers...'Ogbuefi Akuebue, may you live, and all your people. I too will live with all my people... May we have the things with which to live well... May good come to the land of Igbo." (Achebe, 1964, p. 96)

In Igbo tradition, serving and breaking Kolanut with a prayer has a spiritual meaning. In the story, we find many examples of this type of prayer. Ezeulu is visited by the elders of the village to discuss the New Yam Festival. Ezeulu instructs his sons to present Kolanut to the elders before any debate, which they break one by one. On another occasion we see Ezeulu's breaks the Kolanut in six pieces that amazes him. In their belief, if the broken Kolanut has six lobes in it, the spirits want to eat it:

Then he broke the kolanut by pressing it between his palms and threw all the lobes into the bowl on the floor.

"O 0-0 0-0 o 0-0," he whistled. "Look what has happened here. The spirits want to eat."

Akuebue craned his neck to see. "One, two, three, four, five, six. Indeed they want to eat." (Achebe, 1964, p.p. 95-96)

When a high-ranking visitor, a friend, or a family comes to the Igbo people, they have another distinct culture. The host delivers the guest a piece of white chalk, which he uses to paint his toes after drawing some lines on the floor. On several occasion, we find this amusing greeting system of the Igbo people. When Ezeulu's friend Akuebue pays him a visit, he is treated the same way. The gesture of the host conveys whether or not the visitor is welcome. When Ezeulu's son-in-law comes to visit him to return his wife, Ezeulu greets him with this magnificent, one-of-a-kind custom:

"Here is a piece of $n z u$," he said as he rolled the chalk towards his guest, who picked it up and drew on the floor between his legs three erect lines and a fourth lying down under them. Then he painted one of his big toes and rolled the chalk back to Ezeulu who put it away again. (Achebe, 1964, p. 62) 
Aside from chalk painting, the Igbo people have a long tradition of serving palm wine to their visitors. More intriguingly, palm wine is also appreciated by the entire family. We find in the novel when Ezeulu's son brings palm wine for his father's friend Akuebue:

Edogo came in dangling a calabash of palm wine from a short rope tied round its neck. He saluted Akuebue and his father and set down the calabash.

"I did not know that you had palm wine," said Ezeulu.

"It has just been sent by the owner of the door I am carving."

(Achebe, 1964, p. 97)

Thus, Achebe's novel's backdrop is an unmistakable depiction of the Igbo people and their rich culture. The millennium legacy of Igbo society and culture was steadily crumbling with the rise of British colonial rule and the concomitant influence of Christianity. Even then we see in Achebe's description how the Igbo community lives with this as an element of nature. The image of their everyday objects, rich folklore, etc., in Achebe's description is enviable for an African. In the novel Arrow of God, the author depicts various scenarios in which we learn that Igbo folk culture has been passed down from generation to generation. Ezeulu takes the stage during a village meeting and tells a folk tale with a pedagogical tone. Morality and didacticism are frequently seen as motifs in folk stories. Ezeulu tells the narrative in order to warn his Umuaro people against fighting a blame war. Ezeulu warns:

Once there was a great wrestler whose back had never known the ground...He went and beat every spirit that came forward. Some had seven heads, some ten; but he beat them all... He then gave a challenge to his personal god, a little wiry spirit who seized him with one hand and smashed him on the stony earth (Achebe, 1964, p. 27)

One of the characteristics of Igbo culture is the influence of religion, spirituality and unwritten discipline in their daily life. Before making any decision on a major matter of communal concern, the Chief Priest, elders and dignitaries convene to debate it. The fact that they salute everyone at the start of their speech demonstrates their excellent culture. We can see in this story that village assemblies take place at the Nkwo market area on numerous occasions. The speaker takes the stage in front of the audience and addresses the crowd as follows:

“"Umuaro Kwenu!' Nwaka roared.

'Hem!' replied the men of Umuaro.

'Kwenu!' 


\author{
'Hem!' \\ 'Kwezuenu!' \\ 'Hem!' \\ 'I salute you!'” (Achebe, 1964, p. 16)
}

Not only are there many stories in Igbo culture, but there are also many traditional songs and lyrics that are chanted at their events. The Igbos love folk songs so much that even children can memorize them and perform them flawlessly. Traditional folk verses abound in children's games and recreational activities. Their weddings are filled with joyful songs and dancing too. Achebe explains how marriage songs are a part of their folk music and art in the episode about Obika's marriage with Okuata.

“"Kwo-kwo-kwo-kwo-kwo!

Kwo-o-o-oh!

We are going to eat again as we are wont to do!

Who provides?

Who is it?

Who provides?

Who is it?

Obika Ezeulu he provides

Ayo-o-o-o-o-oh!'” (Achebe, 1964, p. 118)

Music and dancing abound in Igbo culture. In this story, there are extensive descriptions and specifics of different prehistoric musical instruments. These instruments are used for a variety of purposes. The village crier plays Ogene, a primitive drum to disseminate any news of importance throughout the community. Another larger drum, the Ikolo, is described in detail Achebe while discussing the Festival of New Pumpkin Leaves.

Its body was carved with men and pythons and little steps were cut on one side; without these the drummer could not climb to the top to beat it. When the Ikolo was beaten for war it was decorated with skulls won in past wars. (Achebe, 1964, p. 71) Almost every event in the Igbo community's culture has a festive tone to it; it is a reason to rejoice. However, two of these festivals stand out: the Pumpkin Lives Festival and the New Yam Feast. The two celebrations share a religious and spiritual link, but the second festival focuses on the agricultural economy, which is the community's lifeblood. These two events are ubiquitous, 
regardless of how much dispute exists between villages or communities. For the Igbos, the New Yam Feast marks the start of the new year. The day for the New Yam Feast is declared by the Chief Priest, who maintains track of the months by looking at the thirteen new moons. This celebration is significant for the people since it is when they begin cultivating new yams in preparation for the New Year. The end of the old harvest season is marked by the New Yam Feast. The Igbos prepare their grounds for the next season's seed yam cultivation. They begin sowing seed yams into the soil as soon as the Chief Priest declares the day.

When it comes to living in a society, it is very common to have disagreements on some matters as well as consensus on others. Achebe's (1964) Arrow of God is a fascinating account of the Igbo community's coexistence. Aside from that, cultural diversity has been considered. Some of the issues of cultural diversity are the result of differences in the internal customs and issues of Igbo society. However, the growing influence of British colonial power and Christianity on the social, cultural, economic, religious and political life of the Igbo people is also very importantly described at various levels of the novel.

Oduche, Ezeulu's son, once brought a python and captured it in a wooden box, according to this novel. This causes havoc in the village, and many begin criticizing Ezeulu for allowing his kid to attend church. The python is regarded sacred in Igboland. Python is seen as a symbol of their forefathers and is revered as such. Idemili is thought to be the owner of the royal python. We learn later in the story that Ezeulu performs unique rites in try to rid himself of the abomination perpetrated by his son.

Apart from this discrepancy, Achebe's story contains hints of other cultural differences. Though the people are devoted to their culture and values, they appear to be adaptable. As a result, their beliefs evolve with time, which is the beauty of their culture. According to the novel, the six villages that are now known as Umuaro believe in multiple deities that eventually merge into one. In the very distant past, when lizards were still few and far be-tween, the six villages-Umuachala, Umunneora, Umuagu, Umueze- ani, Umuogwugwu and Umuisiuzo-lived as different peoples, and each worshipped its own deity. Then the hired soldiers of Abam used to strike in the dead of night, set fire to the houses and carry men, women and children into slavery. Things were so bad for the six vil- lages that their leaders came together to save themselves. They hired a strong team of medicine-men to install a common deity for them. This deity which the 
fathers of the six villages made was called Ulu. Half of the medicine was buried at a place which became Nkwo market and the other half thrown into the stream which became Mili Ulu. The six villages then took the name of Umuaro, and the priest of Ulu became their Chief Priest.(Achebe, 1964, p. 14-15)

The above incident is an example of six different villages being united in special needs, even abandoning their separate deities and accepting one as their savior for all. In the same way, Achebe gives an example of the creation of a completely new deity in the context of special events that proves the flexibility and diversity of Igbo culture. In the novel, Ezeulu tells the past incident of the conflict with the other clan of Okperi and the creation of the new deity.

It was Okperi who gave us a piece of their land to live in. They also gave us their deities - their Udo and their Ogwugwu. But they said to our ancestors - mark my words - the people of Okperi said to our fathers: We give you our Udo and our Ogwugwu; but you must call the deity we give you not Udo but the son of Udo, and not Ogwugwu but the son of Ogwugwu. (Achebe, 1964, p. 15)

Along with the question of deities, there are additional concerns that show the Igbo community's cultural variety. Nwaka and his people share same customs with some differences. Achebe writes: He was one of the three people in all the six villages who had taken the highest title in the land, Eru, which was called after the lord of wealth himself. Nwaka came from a long line of prosperous men and from a village which called itself first in Umuaro. They said that when the six villages first came together they offered the priesthood of Ulu to the weakest among them to ensure that none in the alliance became too powerful. (Achebe, 1964, p.15)

Apart from intra- and inter-clan conflicts and cultural differences, the growing engulfment of Christianity in Igbo culture and society, with the blessings of the British colonial power, progressively takes control. The first disparity occurs when Ezeulu send his son Oduche to the Christian church though Ezeulu says to his son, "I called you as a father calls his son and told you to go and be my eye and ear among those people "(Achebe, 1964, p. 221). Ezeulu, as a man of great wisdom understands the treachery of the British and attempts to put on eye on them. The British had long been able to bring the people under control by establishing a church and school in Okaperi, the land of Ezeulu's mother. They have engaged the people there in various professions including police. They have chosen their Priest as the head of the community. In order to repeat 
the same incident in Umuaro, they offer Chief Priest Ezeulu to take the Warrant Chief title, which Ezeulu vehemently rejects. At first the colonial administrative officer asked Ezeulu to meet them. Chief Priest of Umuaro say, "You must first return, however, and tell your white man that Ezeulu does not leave his hut. If he wants to see me he must come here"' (Achebe, 1964, p. 139). Later in response to the proposal to become the Warrant Chief, he says, "'Tell the white man that Ezeulu will not be anybody's chief, except Ulu"', (Achebe, 1964, p. 174).

One of the most important moments in Achebe's novel is the rejection of the offer of English colonial authority by Chief Priest Ezeulu, which is in fact a "Postcolonial Response" against the British colonial rulers in the novel. This rejection is vital not only for Igbo society, but also for colonial and neocolonial Africa as a whole, as it represents a strong postcolonial counter discourse to European hegemony narrative.

Meanwhile, as a man of great natural knowledge and wisdom, Ezeulu notices how the British colonizer changes his surrounding world. He understands that he is not a match against that power. During his days in custody, he notices a distorted Igbo language uttered by the kids there.

As he ate his meal that night he heard the voices of children wel- coming the new moon. "Onwa atu-o-o-o! Onwa atu-o-o-o!" went up on all sides of Government Hill. But Ezeulu's sharp ear picked out a few voices that sang in a curious dialect. Except for the word moon he could not make out what they said. No doubt they were the children of some of these people who spoke a curious kind of Igbothrough the nose. (Achebe, 1964, p. 163)

As a result, Ezeulu's purposeful delay in declaring the most significant New Yam Festival may have resulted in famine and hunger in Umuaro, prompting the Christian church to establish their God instead of the Gods of Igbos. Ezeulu understands that he cannot stop the British colonizer and their Christian enterprise taking full control in Umuaro but his act of rejection will prevail in the minds of his community as a heroic action.

Finally, the purpose of this paper was to investigate culture and cultural diversity in Igbo life, as well as how Chinua Achebe's (1964) Arrow of God qualifies as a postcolonial response. Needless to say, this well-known story covers a wide range of topics, but culture, cultural diversity within and across communities, as well as the culture that evolves with the advent of Christianity, are the areas that this author focuses. The rich culture and cultural diversity of Igbo society presented in this novel is the postcolonial response to Europe's misleading propaganda about Africa. Ezeulu's 
delay of the declaration of the New Yam Festival causes famine and hunger that provides the opportunity to the Christian missionary to establish their new God among the people. Thus, the novel appears to conclude on a melancholy note, indicating the beginning of the end of the Ulu and Ezeulu's priesthood in Umuaro which is actually not. In fact, the novel closes with Ezeulu triumphantly rejecting the British colonial authority's offer. Even a new Christian, a servant of Colonial officer John Nwodika, compliments Ezeulu's bravery, saying "How many of those who deride you at home can wrestle with the white man as you have done and press his back to the ground?" (Achebe, 1964, p. 179) Ezeulu's rejection is the postcolonial response to the so called European civilization and colonization. In conclusion, his apparent defeat can be seen as a sacrifice that exposes the British colonization's duplicity and betrayal, as is exposed by French Caribbean poet Aime Cesaire (1950) in Discourse on Colonialism:

A civilization that proves incapable of solving the problems it creates is a decadent civilization.

A civilization that chooses to close its eyes to its most crucial problems is a stricken civilization.

A civilization that uses its principles for trickery and deceit is a dying civilization. ( p.31) 


\section{References}

\section{Primary Sources}

Achebe, C. (1958). The Things Fall Apart. Johannesburg, South Africa: William Heinemann. Achebe, C. (1960). No Longer at Ease. Johannesburg, South Africa: William Heinemann.

Achebe, C. (1960). Arrow of God. Johannesburg, South Africa: William Heinemann.

\section{Secondary Sources (Print)}

Ascroft, B, et al. (1995). The Postcolonial Studies Reader. London: Rutledge. Cesaire, A. (2001). Discourse on Colonialism ( J. Pinkham, Trans.). New York: Monthly Review Press (Original work published 1950).

Bhabha, H.K. (1994). The Location of Culture. London and New York: Rutledge. Booker, M. K. (2003). The Chinua Achebe Encyclopedia. USA: Greenwood Press.

Caroll, D. (1980). Chinua Achebe Novelist, Poet, Critic. London: Macmillan. Hawly, C.J. (2004). (Ed.). Encyclopedia of Postcolonial Studies. Westport, Connecticut, London: Greenwood Press

Innes C.L. and Lindforts, B. (1978). (Ed.). Critical Perspectives on Chinua Achebe, USA: Three Continents Press.

Mazuri, A. A. (1986). The Africans: A Triple Heritage. Canada: Little, Brown Company (Canada) Limited.

Okafore G. C. (2001). Achebe the Orator: The Art of Persuation in Chinua Achebe's Novels. USA: Greenwood Press.

Ojaide, T. (2018). Literature and Culture in Global Africa. New York: Rutledge.

Young, J.C. (2001). Post-colonialism: An Historical Introduction. USA, UK \&Australia: Blackwell.

\section{Secondary Source (Web)}


Onyibor, MIS.(2016). "Igbo Cosmology in Chinua Achebe's Arrow of God: An Evaluative Analysis." Open Journal of Philosophy, Vol. 6, 2016, pp. 110-119. http://dx.doi.org/10.4236/ojpp.2016.61011. Accessed 5 June, 2021.

Saikia, N. (2019). "Dynamics of Change and Displacement in Chinua Achebe's Arrow of God." Vol, 4. No. 4, 2019. P. 1056. https://dx.doi.org/10.22161/ijels.4420 ISSN: 24567620 www.ijels.com. Accessed 7 June, 2021

Mgbemere, C.D. (2013). "Cues in Igbo Cultural Matrix: An Analysis of Achebe's Arrow of God." Vol. 2,No. 8, 2013. Pp. 35-42. http://www.ijhssi.org/v2i8(version1).html, Accessed 7 June, 2021

Akwanya, A.N. (2013). "The Power of Unknown in Chinua Achebe's Arrow of God." Vol.2,No.8, 2013. Pp. 35-42. http://www.ijhssi.org/v2i8(version1).html. Accessed 7 June, 2021.

Mokogna, Z. B. (2019). "Insight into the Ibo Socio-Traditional Organization in Chinua Achebe's Arrow of God and Things Fall Apart." International Journal of Linguistics, Literature and Translation, vol. 2, no. 1, Jan. 2019. Accessed, 8 June, 2021. 